
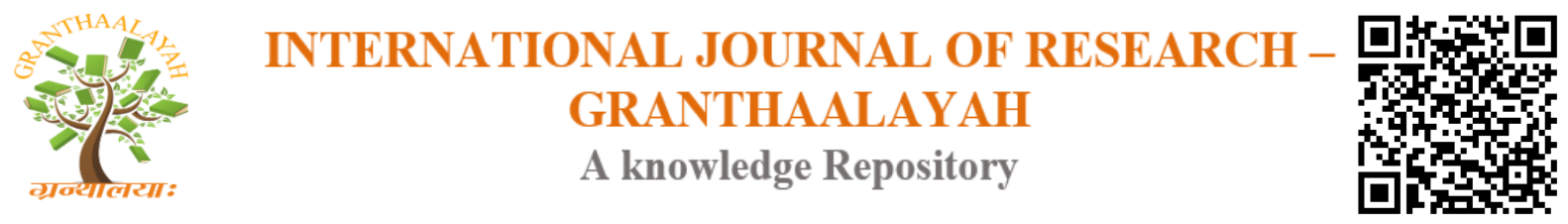

Management

\title{
ALTERNATIVE STRATEGIES ON IMPROVING SMALL AND MEDIUM ENTERPRISES ACCESS TO SEED CAPITAL. A CASE OF DODOMA MUNICIPAL, TANZANIA
}

\author{
Dr.N.Viswanadham*1 \\ ${ }^{* 1}$ Lecturer, Department of Accounting and Finance, school of business, The University of \\ Dodoma, Dodoma
}

\begin{abstract}
A crucial element in the development of the SME sector is access to finance, particularly to bank financing, given the relative importance of the banking sector in serving this segment. Small Medium Enterprises plays important and crucial roles in the economy development of any country. The main purpose of the study is to evaluate the Alternative Strategies on Improving Small and Medium Enterprises (SMEs) S' Access to Seed Capital. This study is descriptive and combines both primary and secondary data methods of data collection. The method of convenience sampling was employed in arriving at the 80 SMEs, which the researchers believe possesses the experience relevant for this study and who have sufficient time and were willing to participate. Data are analyzed and summarized by using both SPSS and excel. Key determinants for seed capital acquisition which are: fair and low interest rates; philanthropy; in-excessive demand for collateral security; less cumbersome procedures and realistic repayment schedule. The study further revealed that high interest rates; lack of finances and unfavorable tax charges as major constraints to the growth of SMEs. In a nutshell, the major challenge could be interpreted to mean lack of seed capital.
\end{abstract}

Keywords: SMEs; Seed Capital; Alternative Financial Sources.

Cite This Article: Dr.N.Viswanadham (2017). "ALTERNATIVE STRATEGIES ON IMPROVING SMALL AND MEDIUM ENTERPRISES ACCESS TO SEED CAPITAL. A CASE OF DODOMA MUNICIPAL, TANZANIA." International Journal of Research Granthaalayah, 5(9), 1-14. https://doi.org/10.29121/granthaalayah.v5.i9.2017.2186.

\section{Introduction}

A crucial element in the development of the SME sector is access to finance, particularly to bank financing, given the relative importance of the banking sector in serving this segment. Firm-level data collected by the World Bank show that access to finance is perceived as one of the main obstacles to doing business (World Bank, various years). A number of studies have shown that financing is a greater obstacle for SMEs than it is for large firms, particularly in the developing world, and that access to finance adversely affect the growth of the SME sector more than that of 
large companies (Schiffer and Weder, 2001; Beck et al, 2005; Beck et al, 2006). It is, therefore, unsurprising that the international development community has listed SME access to finance as an important policy priority.

Various initiatives towards improving the infrastructures and especially roads do provide an added opportunity for SME development. Furthermore, there are several ongoing schemes aimed at strengthening SME service providers such as Small Industries Development Organization (SIDO), Vocational Education Training Authority (VETA), Micro Finance Bank (NMB) and various Industrial Support Organizations. These interventions do provide opportunities for growth of the SME sector. The National Micro Finance Policy covers the provision of financial services to small and micro enterprises in rural areas as well as in the urban sector that are engaged in all types of legal economic activities.

The Government of Tanzania enacted the SMEs development policy (2003-2013) with the aim of fostering job creation and income generation through creation of new SMEs and improving the performance and competitiveness of existing SMEs. Additionally, National Strategy for Growth and Reduction of Poverty II (NSGRP II) has set targets to reduce poverty in both rural and urban areas in Tanzania from 33.6 percent 2007 to 24 percent in 2015. Development of SMEs has been identified to be one among the key strategies to attain the targets of reducing poverty (URT, 2010). The Small Industries Development Organization (SIDO) classifies small scale industries as those establishments which employ people not exceeding 50 while micro enterprises are those projects which employ 10 people or less (URT, 2003).

Table 1: Categories of MSMEs

\begin{tabular}{|l|l|l|}
\hline \multicolumn{1}{|c|}{ Size Category } & \multicolumn{1}{|c|}{ Employment } & \multicolumn{1}{c|}{$\begin{array}{c}\text { Asset (Millions) Including } \\
\text { Land And Building }\end{array}$} \\
\hline Micro enterprises & Less than 10 & Less than 5 \\
\hline Small enterprises & $10-49$ & 5-less than 50 \\
\hline Medium enterprises & $50-199$ & 50-less than 500 \\
\hline
\end{tabular}

Source: Adopted from SME for National Policy on MSMEs (2013)

\section{Materials and Methods}

Small Medium Enterprises plays important and crucial roles in the economy development of any country (Ahmed, 2006). This is because it employs large number of people in Africa especially in Tanzania. Hence paves a way for economic development of the developing countries as portrays Ojo (2009). SMEs has seen operative in economic enhancement in ensuring selfindependence, job creation, and importation of substitution, effective and efficient utilization of local raw materials (Ojo, 2009, Thurik and Wennekers, 2004). Brush and Hart, (2001), sadly noted that there hasn't been any bank or funding agencies with deliberate policy model of encouraging and promoting entrepreneurial finance and resource acquisition. In the same vein, Chigunta, (2001) submitted that if such institutions, are there, their interventions are yet to be registered in the society most probably because budding entrepreneurs have not been able to cope up and stomach their stringent requirements for would be beneficiaries of such funding agencies and financial institutions. Since failure of people of Tanzania to get seed capital severely affects the community livelihood and that SMEs have been proved to alleviate poverty, 
therefore there is a growing need of assessing factors affecting the acquisition of seed capital among entrepreneurs in Tanzania.

The main purpose of the study is to evaluate the Alternative Strategies on Improving Small and Medium Enterprises (SMEs) S' Access to Seed Capital within the Dodoma Municipal and contributions of Financial Institution in Tanzania

\subsection{An overview of Small Business Financing Theory}

In a seminal paper, Ang (1992) demonstrated the importance of acquiring start-up capital for small businesses. While finance theory generally posits that all firms have equal access to financial markets and that all share similar competitive positions (van Auken and Neeley, 1996), small businesses often face severe difficulties compared to large businesses. Numerous supplyside factors - limited information, market imperfections, and agency relationships to name only a few - affect small firms particularly severely and make traditional finance theory inapplicable to their situation (Ang, 1992; McMahon et al., 1993; Petty and Bygrave, 1993). Indeed, sources of finance available to small businesses differ strongly from those available to large companies, and their widespread lack of access to the loan market violates the assumptions of perfect capital markets (Ang, 1992, van Auken and Neeley, 1996). A considerable body of theoretical literature deals with the idea that asymmetric information is at the root of credit rationing (Jaffee and Russell, 1976; Stiglitz and Weiss, 1981; Besanko and Thakor, 1987a, 1987b; Morduch, 1999). This idea rests on two assumptions about the lack of financial capital observed among small and micro businesses. The first assumption is that lenders cannot distinguish between high and lowrisk borrowers, and borrowers cannot easily signal their own risk-taking behavior, whereas the second assumption is that loan contracts are subjected to limited liability. According to this theory, credit is rationed when the amount lenders are willing to offer to borrowers is limited, or when no lender is willing to make a loan to a borrower. Despite the ongoing theoretical discussion, little consensus has been reached about whether credit rationing is an economically significant phenomenon (Berger and Udell, 1992). With regard to the demand side of loan markets, there has been less theoretical research. Based on the asymmetric information approach, the Pecking Order Theory claims that businesses adhere to a hierarchy of financing sources, preferring internal financing when available, and preferring debt over equity when external financing is required (Myers, 1984).

\subsection{The distinctive challenges of SME finance}

Any potential provider of external debt or equity finance will want to monitor the company to determine whether it is acting in accord with the initial contract, to follow the progression of the firm and to have the means to oblige the user of funds to respect the interests of the provider of funds. There are numerous reasons why doing this effectively is more problematic for SMEs than for larger firms. Hence, banks are more likely to engage in credit rationing (i.e. not extending the full amount of credit demanded, even when the borrower is willing to pay higher rates) to SMEs than to larger companies (Stieglitz and Weiss, 1981; Hoff and Stieglitz, 1999).

Trade credit, i.e. credit supplied by non-financial entities, has always been an important component of SME finance and many analysts argue that the development of trade credit is an 
important element in assuring adequate finance for SMEs in emerging markets. There are also potential principal/agent problems. The provider of credit will seek to require the borrower to act so as to maximize the probability that the loan is repaid, while the borrower may seek higher risk/higher return solutions. Once financing is received, the entrepreneur may be motivated to undertake excessively risky projects, since all of the upside of the project belongs to the entrepreneur, while the lender prefers a less risky project that increases the probability that the loan will be repaid. This problem, which is potentially present in all lending, is more serious for smaller firms than for larger firms because of the blurring of the line between the firm and the entrepreneur and due to information asymmetries (Storey, 2005).

Asymmetric information is a more serious problem in SMEs than in larger firms. The entrepreneur has access to better information concerning the operation of the business and has considerable leeway in sharing such information with outsiders. However, the entrepreneur is also likely to have less training/experience in business than those in a larger company, although more adapted to operating in an uncertain environment. Hence, it may be difficult for the outside provider of financing to determine whether the entrepreneur is making erroneous decisions or for the outsider to understand the business adequately. In addition, the entrepreneur may have incentives to remain opaque, not only in dealings with financiers, but also with other outsiders such as regulators and tax authorities. The analysis of credit rationing is believed to provide special insights into problems of finance in developing and emerging markets. Thus, this argument has become part of the analysis generally applied to problems of finance in emerging markets (Storey, 1995).

\subsection{Sustainable sources of funds for SMEs}

The current reforms in Tanzania have resulted in liberalization of the financial sector to a great extent. This has led to establishment of a number of banks including the National Micro Finance Bank, liberalization of financial rates and establishment of a stock exchange market. In spit e of all these, the SME sector is facing a major constraint in accessing finance. This limits their capacity to survive, increase capacity, upgrade its technologies and even in many cases, expand $t$ heir market $\mathrm{s}$ and improve management or raise productivity and eventually increase incomes (Kimei, 2001).

\subsection{Exploring SMEs financial resource acquisition challenges}

A combination of various resource acquisition challenges have continued to endanger the ability of small firms in Africa to survive in today's global economic system. Some of the key challenges include but not restricted to: lack of financial support; poor infrastructure; lack of government support and assistance; international expansion issues and globalization of markets and production. First and foremost is startup ventures lack of Financial Support. Hill, (2009) submitted that a combination of developments discourses and national challenges endanger the ability of entrepreneurs to survive in today's global economic system. He also mentioned the same challenges and just as the field findings highlights, lack of financial support has been placed at the centre and is the biggest challenge facing entrepreneurs. Notwithstanding existing policies on financial support for entrepreneurs, very few entrepreneurs receive financial help when they need it. Mambula (2002) in his studies undertaken in Nigeria also considered lack of 
financial support as the number one constraint in facing entrepreneurs. Mambula (2002) further rightly observed that entrepreneurs deem procedures for securing business loans from banks cumbersome, and the collateral demanded for such loans excessive. Mambula (2002) rightly observed that notwithstanding existing policies on financial support for small businesses, handful entrepreneurs obtain financial help when they need it. Closely related to lack of finance is the fact that small business assistance from governments of many African nations is feeble and insufficient. To this effect some writers have advised the governments in Africa to consider providing financial aid, counseling, and other forms of assistance and protection to entrepreneurs and small business startups (Mambula, 2002).

\subsection{Scope of the Study}

This research study is aiming to provide vision with regard seed capital challenges for small and medium enterprises (SMEs) in Dodoma Municipal.

\subsection{Research Design}

According to Saunders et al (2009, P. 159), a research design is the general plan of how you will go about answering your research questions. A research design refers to the way a study is planned for the purpose of getting answers to the assumptions or questions made by the researcher (Leedy and Ormrod, 2005; Collins and hussy, 2003). The study embrace a case study since it holds an important advantage in enhancing the opportunity for holistic view of a specific phenomenon or series of events (Yin, 1984; Eisenrahardt, 1989).

\subsection{Sampling Technique}

The method of convenience sampling was employed in arriving at the 80 SMEs, which the researchers believe possesses the experience relevant for this study and who have sufficient time and were willing to participate (Morse, 1998). This technique, convenience sampling, involves obtaining responses within the sample frame from willing respondents and also their availability for the study.

\subsection{Data Collection Techniques and Instruments}

This study is descriptive and combines both primary and secondary data methods of data collection.

\subsection{Data Analysis}

Data are analyzed and summarized by using both SPSS and excel and the appropriate recommendation and conclusion were drawn. Data are analyzed using both qualitative and quantitative techniques. Secondary data are analyzed using documents reviews and available literature. 


\section{Results and Discussion}

It is worthwhile to note that the study used a representative sample that took into cognizance the need for involving respondents drawn from many SME sectors namely: Retail \& Wholesalers; Manufacturing; Real Estate; Farming ; Vegetable dealers; Hotels \& Restaurant Construction and Stationary. This was adhering to guarantee data reliability that is free from biasness and of course collection of well-informed data and having a representative sample.

The educational levels of SME managers whereupon it showcases that on the retailer wholesale category $20 \%$ of the managers were high school certificate holders while $80 \%$ hand completed grade 7. The study concludes that the majority of SMEs involved in this study have been operation for a period of not more than 5 years. The implication is that there could be a great number of SMEs that could have died a natural death due to probably the lack of seed capital. The fact that they are few SMEs that have lived for more than 5 years suggests that the road to seed capital acquisition is full of thorns. The Study shows that the majority of SMEs (70\%) have only employed between $1-5$ employees compared to 20\% SMEs who have only employed between 5 - 10 employees; followed by $6.25 \%$ of SMEs who have employed between $10-20$ employees and lastly $3.75 \%$ of SMEs who have employed over 20 employees. The implication is that many SMEs struggle to employ more than 5 employees because of the level of their growth. The study can therefore safely conclude that the majority of SMEs fall under the Micro enterprises category and a few falls and Small enterprises with only an insignificant number of Medium enterprises.

The Study indicates that the SMEs who has a monthly turnover of Less than 1000000 Tshs constitutes 30\%; those that have a turnover between 1 and 5 million $\mathrm{THz}$ are in the majority as they constitute 35\%; those with a monthly turnover that lies between 6 and 10 million $\mathrm{THz}$ constituted $23.75 \%$ and those with a monthly turnover between 11 and 20 million $\mathrm{THz}$ were $8.75 \%$ whereas on the least category were those who had a monthly turnover of over 20 million $\mathrm{THz}$ who constituted 2.5

\subsection{Strategies to improve SMEs' access to finance acquisition}

Having have realized the challenges the SMEs face in their search for seed capital, the study further asked respondents to give the most preferred (financial acquisition method) way of funding startup businesses to which $43 \%$ of respondents reveals that they prefer SACCOS; $40 \%$ prefer Business Angels; 9\% said they prefer personal Savings; 5\% said they prefer Micro Financial Institutions and the least preferred is Bank credit/loan as suggested by $3 \%$ of respondents as highlighted on [the pie chart below] figure 1. 


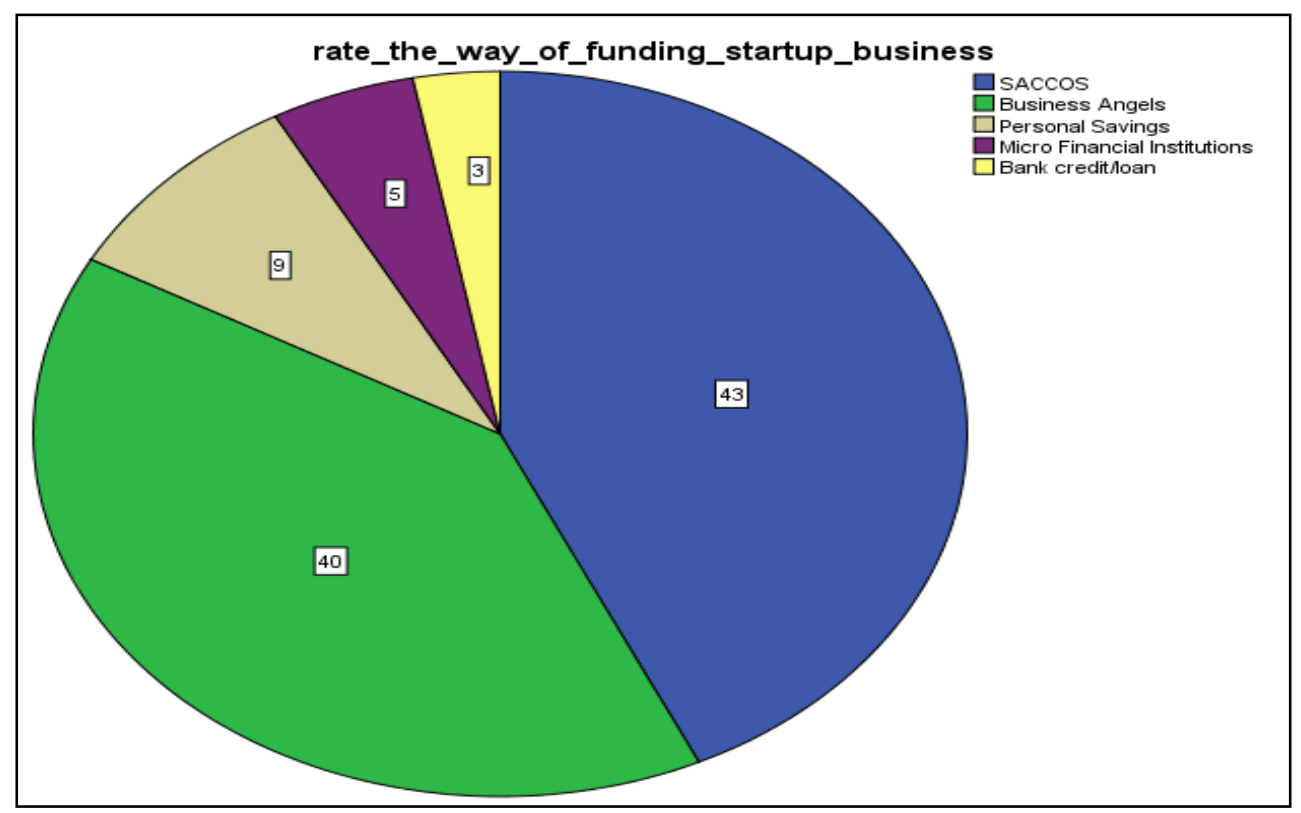

Figure 1: The most preferred way of funding startup businesses

Source: Author Field Findings (2016)

The study identifies that there are a few SMEs who prefer Microfinance institutions and banks as funding sources for their startups but rather the majority of SMEs in Dodoma prefer SACCOS who most probably have fair interests rate and less stringent requirement regarding loan applications. The second preferred way of funding startups in Dodoma is business angels whose motives are to some extent philanthropic and they usually don't demand unaffordable collateral security and other difficult loan requirements. The study can further conclude that in the event that the available funding requirements are not fair hence rendering the bottleneck to seed capital acquisition, the startup SMEs would embrace bootstrapping strategies as startup funding application, thus they prefer personal savings. As such, the best method and strategy to improve SMEs' access to finance acquisition is to make collateral security affordable and make other loan application prerequisites releasable against those that are beyond reach.

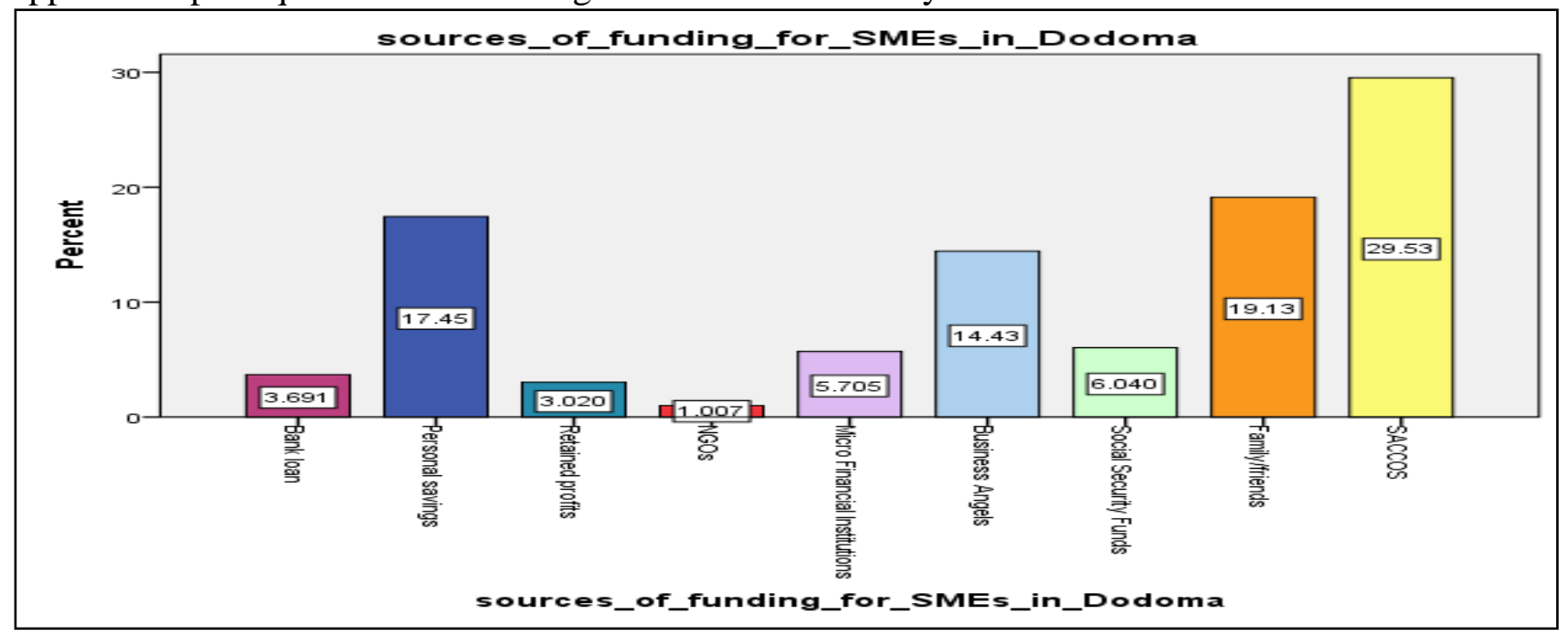

Figure 2: Sources of funding favorable to SMEs in Dodoma

Source: Author Field Findings (2016) 
The study therefore concludes that while there are varieties sources of seed capital which include but not limited to: Banks; Government; NGOs; Microfinance institutions; Donor Agencies; Business Angels and Family, many funding institutions have stringent requirements expressively resulting in SMEs in Dodoma to opt for SACCOS [who most probably have fair interests rate and less stringent requirement] and business angels [who are driven by philanthropic attitudes] as also supported by Alemany, (2007) who described business angel as private investors that invests part of their own wealth and time in early stage innovative companies. Apart from getting a good return, business angels expect to have fun. Alemany, (2007) estimated that angel investment amounts to three times venture capital. Lastly, the study reveals that if the worse goes to the worst the SMEs under study would opt for bootstrapping strategies. They would only seek funding from banks and other microfinance institutions at the third phase of the business growth, thus from: bootstrapping phase; networking stage and the strengthening networking stage.

Taking into cognizance of the excessive funding requirements stipulated (by both banks and other financing [funding/lending] institutions) which include but not limited: formal letter of application; comprehensive business profile; full names of management team and management CV's; actual audited accounts for the past three years; detailed age wise analysis of trade debtors, creditors and up to date stocks; cash flow projections for the coming 5 year; and a whole lot of prerequisites as submitted by (Mambula,2002), the study was interested to discover the major constraint to the growth of SMEs. ; secondly to explore if SMEs are willing to employ more hands in the future; thirdly to examine SMEs' willingness to establish more branches and lastly investigating their readiness to accept professional advice. The desired effect was to deduce some strategies based on their views to these issues. Thus the next figure explores the major constraint to the growth of SMEs.

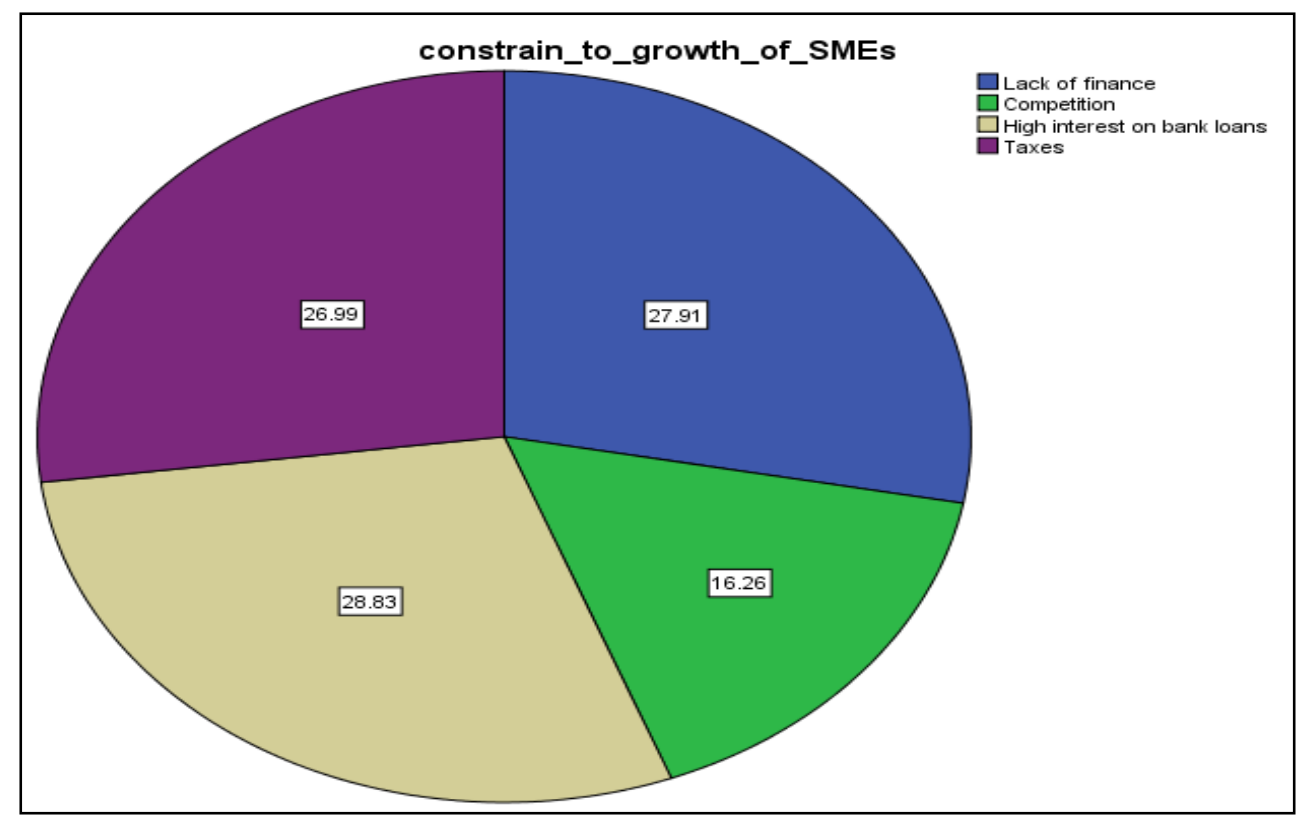

Figure 3: Exploring major constraint to the growth of SMEs

Source: Author Field Findings (2016)

The figure above reveals that the major constraints to SMEs' growth is high interest rate on bank loans which was rated $29 \%$ followed by lack of finance which was rated $28 \%$ followed by taxes 
which was rated $27 \%$ and lastly competition which was rated $16 \%$. The implication is that high interest rates; lack of finances and unfavorable tax charges are the major constraints to the growth of SMEs. On the other hand, competition could be another constraint though the implication is that it does not affect the majority as suggested by the least percentage of responses. The study therefore conclude high interest rates; lack of finances and unfavorable tax charges as major constraints to the growth of SMEs. In a nutshell, the major challenge could be interpreted to mean lack of seed capital. The views above are in agreement with Hill, (2009) who submitted that a combination of developments discourses and national challenges endanger the ability of entrepreneurs to survive in today's global economic system. He also mentioned the same challenges and just as the field findings highlights, lack of financial support has been placed at the centre and is the biggest challenge facing entrepreneurs. Furthermore, the respondents were asked on whether or not they would be willing to employ many employees and their responses are captured below.

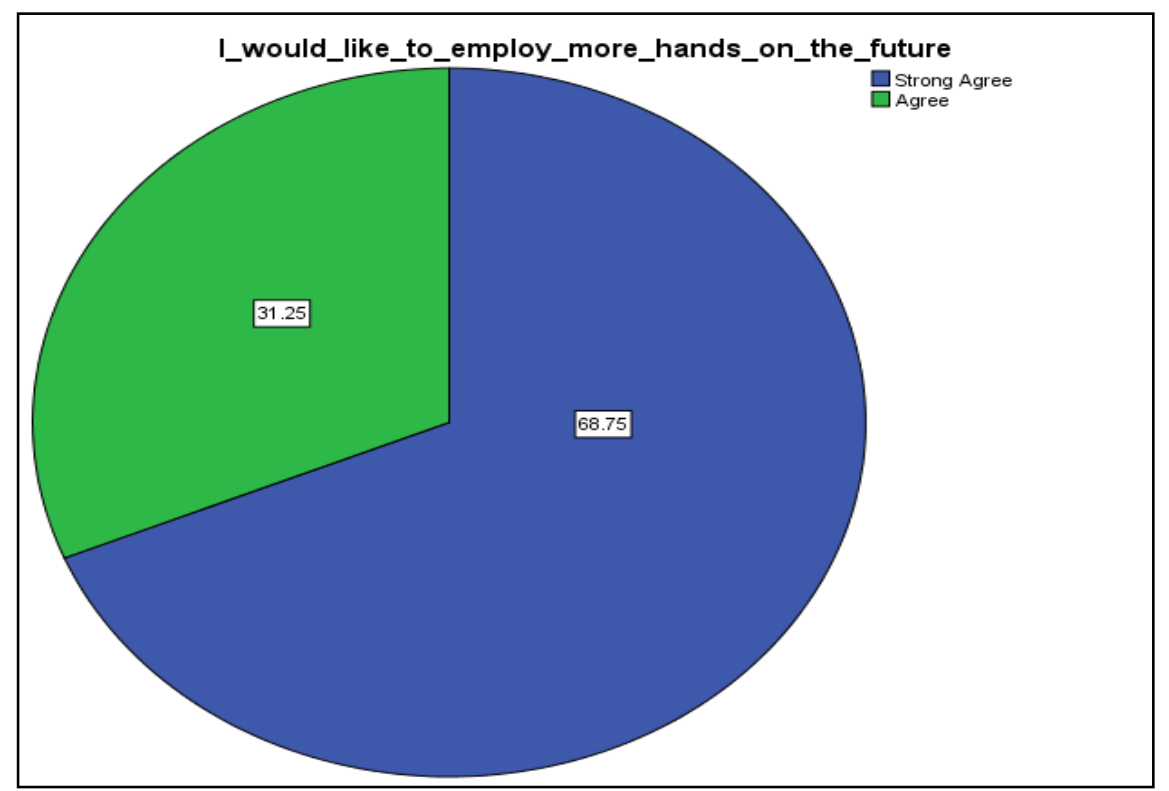

Figure 4: Assessing SMEs' willingness to employ many employees Source: Author Field Findings (2016)

Respondents overwhelmingly indicated that they are willing to increase the number of their employees as suggested by the percentage of respondents who strongly agreed [69\%] and those who agreed [31\%] respectively as opposed to none who either were undecided; disagreed or strongly disagreed. This implies that if all was in their [SMEs] favor, thus if they had access to seed capital, they will increase their employees hence improving productivity and performance of their growth. Moreover, the study explored the SMEs' willingness to establish more branches to which the majority both strongly agreed and agreed as highlighted on the following pie chart. 


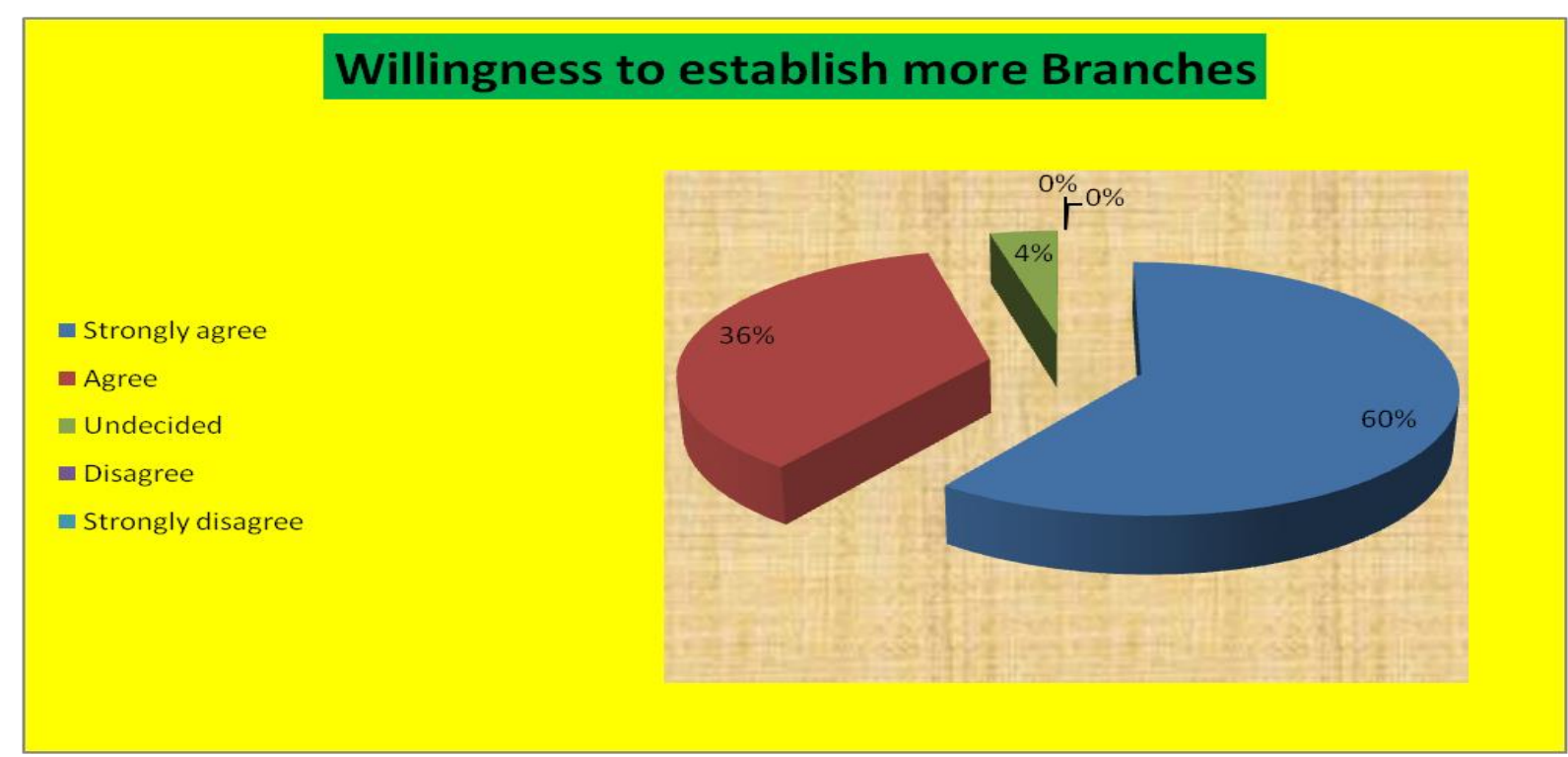

Figure 5: Assessing SMEs' willingness to establish more branches Source: Author Field Findings (2016)

$60 \%$ of respondents strongly agreed and $36 \%$ agreed that they were willing to establish more branches save for $4 \%$ who indicated that they were undecided; none either disagreed or strongly disagreed. The bottom line here is that the majority of SMEs are eager to expand their businesses. The respondents were further asked to demonstrate their readiness to accepted professional advice from banks when given credit and the majority who constituted $40 \%$ showed they were undecided whereas 14 disagreed. Positively, those who strongly agreed constituted $20 \%$ while those who agreed constituted $26 \%$ with none who strongly disagreed as enshrined on [the following pie chart] figure 4.26 .

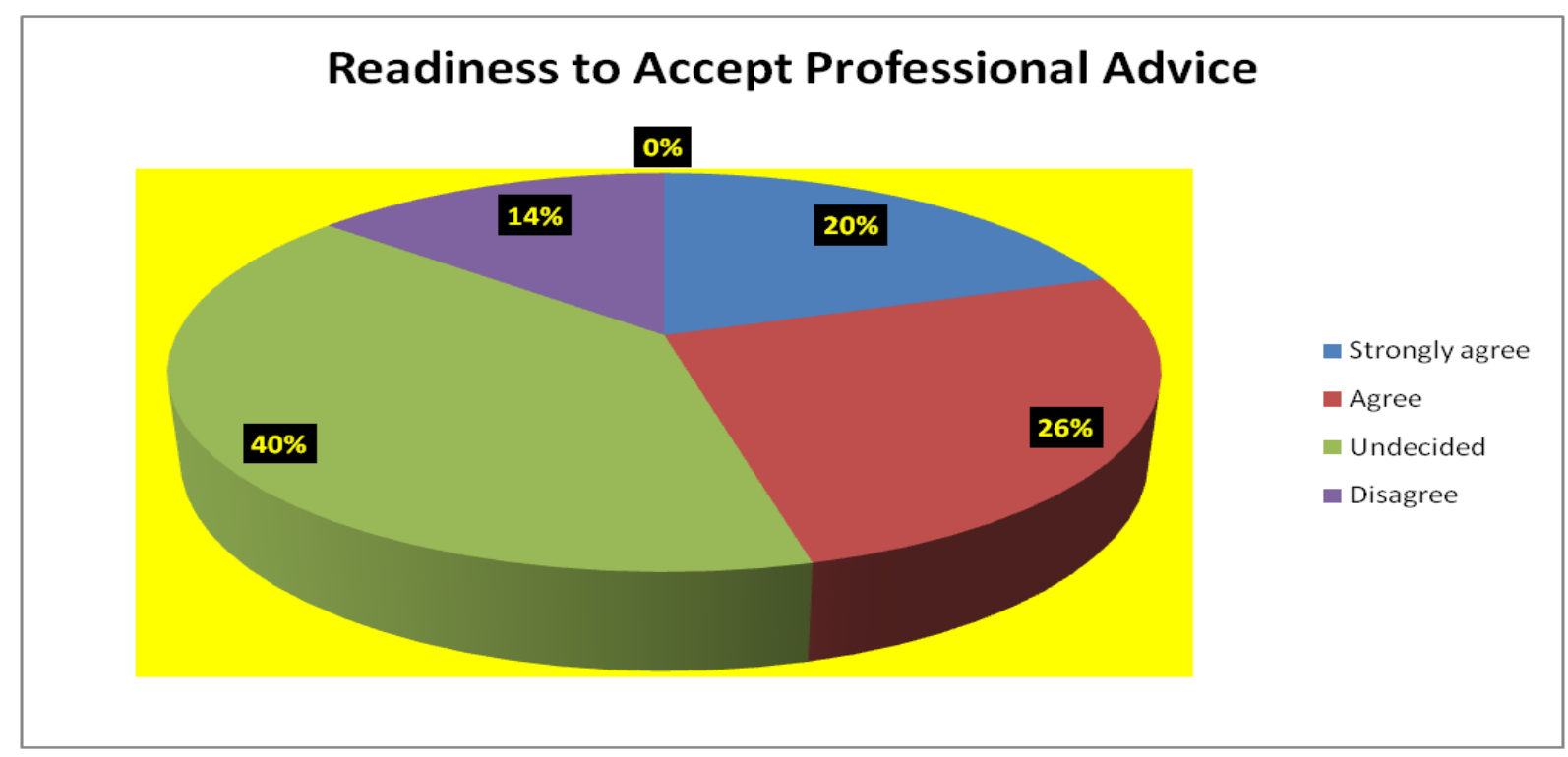

Figure 6: Assessing SMEs' readiness to accept professional Advice Source: Author Field Findings (2016) 
The implication is that a combination of those who were undecided and disagreed is that they are skeptic and doubt if they will ever receive help from the banks considering their inability to meet the banks' expectations. This also shows that the banks have not done enough to help the SMEs. On a positive note, a combination of those who strongly agreed and agrees is a demonstration that there exist SMEs who are optimistic that if at all they could get seed capital for their businesses the sky is the limit. However, this study conclusively posits with a heavy heart that most probably there hasn't been any bank or funding agencies with deliberate policy model of encouraging and promoting SMEs activity in Tanzania and Dodoma in particular. If such institutions, are there, they could be very few with less impact and their robust interventions are yet to be registered in the society most probably because SMEs have not been able to cope up and stomach their stringent requirements for would be beneficiaries of such funding agencies and financial institutions. The following table showcases the responses of entrepreneurs regarding the determinants for their resource acquisition approach.

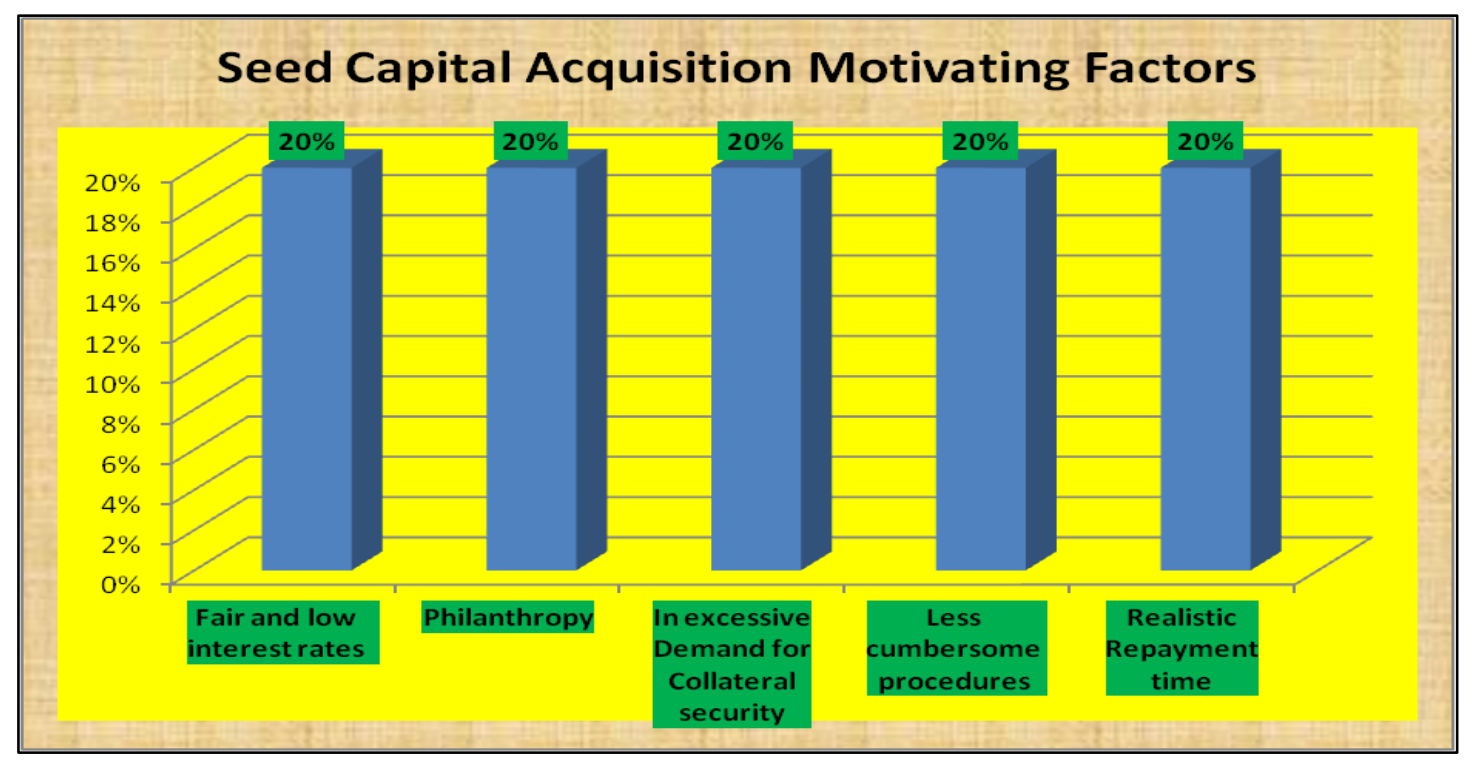

Figure 7: Factors motivating SMEs in their choice for Seed capital acquisition Source: Author Field Findings (2016)

The results given above indicate that the key determinants for seed capital acquisition which are: fair and low interest rates; philanthropy; in-excessive demand for collateral security; less cumbersome procedures and realistic repayment schedule. It is therefore suffice to stress that the task for selecting financial support is a matter of choice for different SMEs. Given the requirements and bottlenecked resource acquisition, many SMEs have expressively opted for financial bootstrapping whereby they just use a combination of the available funds and manpower they have to start up their venture. This is supported by Brush and Hart, (2001) who described financial bootstrapping as a term used to cover different methods for avoiding using the financial resources of external investors. According to Winborg and Landström, (2001), financial bootstrapping rivets risks for the founders but allows for more freedom to develop the venture. They are various types of financial bootstrapping which include: Owner financing, Sweat equity, Minimization of accounts payable, joint utilization, minimization of inventory, delaying payment, subsidy finance and personal debt. If funding institutions turn difficult, the SMEs would embraced any form of the said financial bootstrapping. 


\section{Conclusion}

The Study Concludes that there are a few SMEs who prefer Microfinance institutions and banks as funding sources for their startups but rather the majority of SMEs in Dodoma prefer SACCOS who most probably have fair interests rate and less stringent requirement regarding loan applications.

The study further revealed that high interest rates; lack of finances and unfavorable tax charges as major constraints to the growth of SMEs. In a nutshell, the major challenge could be interpreted to mean lack of seed capital. In the event funding institutions become flexible in their requirements for loan applications, respondents registered their willing to increase the number of their employees; the number of branches and willingness to accept professional advice and suggested by the majority of SMEs who submitted that the key determinants for seed capital acquisition are: fair and low interest rates; philanthropy; in-excessive demand for collateral security; less cumbersome procedures and realistic repayment schedules. It is to this effect that the study conclusively posits with a heavy heart that most probably there hasn't been any bank or funding agencies with deliberate policy model of encouraging and promoting SMEs activity in Tanzania and Dodoma in particular.

\section{References}

[1] Abor, J. and N. Biekpe, 2006. "SMEs' Access to Debt Finance: A Comparison of Male- Owned and Female-Owned Businesses in Ghana", International Journal of Entrepreneurship and Innovation, 7(2), pp. 105-112.

[2] Alay - Organ, L. (2012) Business Angels: There's more to it than Money for Entrepreneurs, Alumni Magazine.

[3] Alemany, L. (2014) "Entrepreneurial Finance: Lecture Slides, ESADE Master in Innovation and Entrepreneurship Year 2013/2014", ESADE, and Barcelona.

[4] Aryeety, et al. (1994).Social Science Research: Conception, Methodology and Analysis.Makerere University Printery

[5] Ante, S. (2008) Creative Capital: George Doriot and the Birth of Venture Capital, Harvard Business School Press, Boston

[6] Åstebro T., \& Bernhardt I. (2003). Startup financing, owner characteristics and survival. Journal of Economics and Business, 55, 303-319.

[7] Atherton A. (2012). Cases of startup financing: An analysis of new venture capitalization structures and patterns. International Journal of Entrepreneurial Behaviour \& Research, 18(1), 28-47.

[8] Ahmed, S., Landström, H. and Månsson, N. (2006), what do we mean when we talk about business angels? Some reflections on definitions and sampling, Venture Capital,

[9] Baptista R. \& Mendonça J. (2009). Proximity to knowledge sources and the location of knowledge-based startups. The Annals of Regional Science, 45(1), 5-29.

[10] Basu Ch., (2013) Difference between Seed Funding \& Early-Stage Funding. Small Business Financing

[11] Basonko and Thakor. (1987). Strategic resources: Traits, configurations and paths to sustainable competitive advantage. Strategic Management Journal 15:

[12] Berger A., Cowan A., \& Frame S. (2011). The Surprising Use of Credit Scoring in Small Business Lending by Community Banks and the Attendant Effects on Credit Availability, Risk, and Profitability. 
[13] Bernery, D. (2007), Raising Venture Capital for the Serious Entrepreneur, McGraw-Hill Book Company, New York.

[14] BOT (2012), financial innovations and financial inclusion in Tanzania: $16^{\text {th }}$, Comference Nov. $26^{\text {th }},-27^{\text {th }}$, Arusha Tanzania

[15] Brown M., Degryse H., Hoewer D., \& Penas M. (2012). How Do Banks Screen Innovative Firms? Evidence from startup Panel Data. ZEW - Centre for European Economic Research, Discussion Paper No. 12-032.

[16] Brush, C., P. G. Greene, and M. M. Hart, (2001). From initial idea to unique advantage: The entrepreneurial challenge of constructing a resource base. Academy of Management Executive15 (1)

[17] Cassar G. (2004). The financing of business startups. Journal of Business Venturing, 19(2), 261283.

[18] Chigunta, F. (2001), "Youth Livelihoods and Enterprise Activities in Zambia". Report to IDRC, Canada.

[19] Colombo Massimo G., \& Grilli, L. (2005) Founders' human capital and the growth of new technology- based firms: A competence-based view, Research Policy, 34, 795 - 816.

[20] Cook, P. and F. Nixson, 2000. "Finance and Small and Medium-Sized Enterprise Development", IDPM, University of Manchester, Finance and Development Research Programme Working Paper Series, Paper No 14.

[21] Davila A., Foster G., \& M. Gupta (2000). Venture-Capital Financing and the Growth of Startup Firms. Journal of Business Venturing, 18(6), 689- 708.

[22] Dean B. \& Giglierano J. (1990). Multistage financing of technical startup firms in Silicon Valley, Journal of Business Venturing, 5(6), 375-389.

[23] Erdem, K. 2011. Employment Implications of Small Scale Industries in Developing Country

[24] Fisher, E. and R. Reuber, 2000. "Industrial Clusters and SME Promotion in Developing Countries", Commonwealth Trade and Enterprise Paper No. 3

[25] Freear J., \& Sohl, Wetzel W. (1995). Angels: Personal Investors in Venture Capital Market, Entrepreneurship and Regional Development, 7, 85-94.

[26] Ge, B., Hisrich, R.D. \& Dong, B., (2009), Networking, Resource Acquisition and the Performance of Small and Medium-Sized Enterprises: An Empirical Study of Three Major Cities in China, Managing Global Transitions 7 (3):

[27] Gibson, Alan (1997) "Business development services - core principles and future challenges". Small Enterprise Development V8 N3, London.

[28] Gockel, P. and Akonea, J. (2011), the Money of Invention, Harvard Business School Press, Boston

[29] Hisrich, R.D. \& Peters, M.P. \& Shepherd, D.A. (2010) Entrepreneurship (latest edition) McGrawHill.

[30] Hodkinson, P., \& Hodkinson, H. (2001).The strengths and limitations of case study research. Cambridge: The Learning and skills Development Agency Conference.

[31] J., \& Mickiewicz, T. (2011). Startup financing in the age of globalization: Emerging Markets Finance and Trade. 47(3), 23-49.

[32] Karimba, P. et al., (2000), "Youth Livelihoods and Enterprise Activities in Malawi". Report to IDRC, Canada.

[33] Kocis, J., Bachmann, J., Long, A. and Nickels, C. (2009), Inside Private Equity, Wiley, Hoboken. ISBN 0-47-042189-4.

[34] Kothari C.R, (2004).Research Methodology, Mumbai, New age international.

[35] Kotha, R., \& George G. (2012). Friends, family or fools: Entrepreneur experience and its implications for equity distribution and resource mobilization, Journal of Business Venturing, 27, 525-543. 30.

[36] Lahm R., \& Little H. (2005). Bootstrapping business startups: a review of current business practices, Conference on Emerging Issues in Business and Technology 
[37] Leung, A., J. Zhang, P.K.Wong, and M.D.Foo. (2006). the use of networks in human resource acquisition for entrepreneurial firms: Multiple 'fit' considerations. Journal of Business Venturing 21(5)

[38] López, G. J. and A. C. Aybar, (2000). “An Empirical Approach to the Financial Behavior of Michael et al, (2009), 'Venture capital in crises, Venture Capital, 11(4), 279-85.

[39] Meyers, S. (1984), "Education and Training for the Informal Sector: Reflections on an International Research Project', in 'Transformations", No.39.

[40] Paul P., Whittam G., \& Wyper J. (2007). The pecking order hypothesis: does it apply to startup firms? Journal of Small Business and Enterprise Development, 14(1), 8-21.

[41] Saunders, Mark, Lewis Philip and Thornhil, Adrian (2012).Research methods for business student. England. Pearson Education Ltd

[42] Sekeran Uma and Bougie, Roger. (2010). Research methods for business. New Delhi India: John Wiley \& sons.

[43] Sekeran, Uma and Bougie, Roger. (2003). Research methods for business: A skill building approach.New York: John Wiley \& Sons, Inc.

[44] Sowah, D.J., Mason, C.M., Harrison, R.T., (2003), Angel Investment Decision Making as a Learning Process, Working Paper 10-05, University of Strathclyde

[45] Wang, Q.X., andG.M.Bao.2007. Social network, resource acquisition and the growth ofsmes. Proceedings of Management Engineering 4:57

[46] White and Kenyon (2000). "Enterprise-Based Youth Employment Policies, Strategies and Programmes". Drat Report to ILO, Geneva.

[47] Winborg, J. and Landström, H. (2001), 'Financial Bootstrapping in Small Businesses: Examining Small Business Managers’ Resource Acquisition Behaviors’, Journal of Business Venturing.

*Corresponding author.

E-mail address: viswanadh214@ gmail.com 